Article

\title{
Implications of Fagopyrin Formation In Vitro by UV Spectroscopic Analysis
}

\author{
Anatolij Kosyan ${ }^{1}$ and Oksana Sytar ${ }^{1,2, *}$ \\ 1 Department of Plant Biology, Educational and Scientific Center "Institute of Biology and Medicine", \\ Taras Shevchenko National University of Kyiv, Hlushkova Avenue, 2, 03127 Kyiv, Ukraine; a_kosyan@ukr.net \\ 2 Department of Plant Physiology, Slovak University of Agriculture in Nitra, A. Hlinku 2, 94976 Nitra, Slovakia \\ * Correspondence: oksana.sytarl@gmail.com
}

check for updates

Citation: Kosyan, A.; Sytar, O. Implications of Fagopyrin Formation In Vitro by UV Spectroscopic Analysis. Molecules 2021, 26, 2013. https://doi.org/10.3390/ molecules26072013

Academic Editors: Bruno Botta and Changsheng Zhang

Received: 24 February 2021

Accepted: 29 March 2021

Published: 1 April 2021

Publisher's Note: MDPI stays neutral with regard to jurisdictional claims in published maps and institutional affiliations.

Copyright: (c) 2021 by the authors. Licensee MDPI, Basel, Switzerland. This article is an open access article distributed under the terms and conditions of the Creative Commons Attribution (CC BY) license (https:/ / creativecommons.org/licenses/by/ $4.0 /)$.

\begin{abstract}
The present work aims at studying the possible biosynthesis of fagopyrin in buckwheat plants with an attempt to address the existing gaps. The developed method of differential spectrophotometry can be used for identification of naphthodianthrones fagopyrins. It was found that in the vegetative mass of buckwheat plants, fagopyrin precursor-2-(piperidine-2-yl)-emodindianthron could be present. As fagopyrin can be produced by light effect, the temperature factor may influence the formation of protofagopyrin in vitro. An optimum temperature range was estimated for protofagopyrin formation. A possible fagopyrin biosynthesis under in vitro conditions was suggested.
\end{abstract}

Keywords: naphthodianthrones; fagopyrin; hypericin; Fagopyrum; differential spectrophotometry

\section{Introduction}

Buckwheat (Fagopyrum esculentum L.), a traditional pseudocereal crop (Polygonaceae), is widely known as a food and medicinal plant. Different parts of Buckwheat plants, especially inflorescences, have already been studied for flavonoids and phenolic acids [1,2]. Buckwheat is expected to be an even more important plant in agriculture as a food crop as it is part of the dietary habits in many countries, including those of Europe, Asia and America [3]. Buckwheat research has gained significant interest recently due to the presence of some less studied secondary metabolites with antioxidant and anticancerogenic effects [4-6].

Fagopyrin is a naphthodianthrone with anticancerogenic effect, which was isolated for the first time in 1943 from the blossoms of the red flowering variety of Fagopyrum esculentum, a plant known since 1833. The chemical structure of fagopyrin (red, fluorescent pigment) has been deduced only in 1979 [7]. The structure of fagopyrin is very similar to that of hypericin, which is present in St. John's wort (Hypericum perforatum L.). The aromatic structure of fagopyrin is like that of hypericin, differing only in the presence of two symmetrically placed 2-piperidinyl groups in fagopyrin.

Naphthodianthrone compound present in Fagopyrum sp. (fagopyrin, fagopyrin derivatives) have a photosensitizing effect [8] which is currently used for photodynamic therapy of cancer cells [9]. fagopyrin and hypericin have also shown antifungal effect on pathogenic fungi and spoilage yeasts $[10,11]$. Recent studies have identified fagopyrin by HPLC $[12,13]$ but its exact quantification, isolation and biosynthesis is still under discussion. Tavčar Benković et al. (2014) with the help of HPLC analysis have determined the structures of two new derivatives (fagopyrin A and fagopyrin E) and proved the existence of protofagopyrin that can transform into fagopyrins upon light exposure [14]. Therefore, in the present work, we have attempted to study ways of fagopyrin formation with the aim to address the gaps in fagopyrin biosynthesis.

The highest quantity of fagopyrin derivatives was observed in inflorescences and lower amount in leaves of common buckwheat [15]. Ozbolt et al. (2008) found in leaves of 
common buckwheat (Fagopyrum esculentum L.) 3 times higher fagopyrin content compared to the stems [16].

The development of an effective method to determine the quantity of fagopyrin was problematic as the buckwheat leaf extracts contain a considerable amount of chlorophyll [17]. The content of fagopyrin derivatives can be determined with UV-vis spectrometer at $590 \mathrm{~nm}$, i.e., the wavelength used for evaluating hypericin concentrations [16,18]. Differential extraction of flavonoids and fagopyrin derivatives from the green parts of buckwheat is possible by the adjustment of extraction conditions [18]. Until recently, the isolation and extraction attempts of fagopyrin was under development with the use of spectrophotometric, TLC and HPLC analysis [14]. The preliminary analysis of previous studies with known parameters of extraction of fagopyrin for spectrophotometric analysis is shown in Table 1. As we see in the study of Sha et al., 2018, fagopyrins in buckwheat leaves was extracted by $90 \%$ acetone, methanol, $60 \%$ glacial acetic acid and $80 \%$ tetrahydrofuran. Then, $90 \%$ acetone was used as the best extractant, and UV-vis spectrophotometry was considered the simple and fast analytical method [19].

Table 1. The known parameters of extraction of fagopyrin for spectrophotometric analysis.

\begin{tabular}{|c|c|c|c|c|c|c|}
\hline Method & Plant Weight & $\begin{array}{l}\text { Solvent for } \\
\text { Extraction }\end{array}$ & $\begin{array}{c}\text { Time and Conditions } \\
\text { of Extraction }\end{array}$ & $\begin{array}{l}\text { Supernatant } \\
\text { Solvent }\end{array}$ & Wavelength & References \\
\hline $\begin{array}{l}\text { A spectrophotometric } \\
\text { method }\end{array}$ & $80 \mathrm{mg}$ & $\begin{array}{c}80 \% \\
\text { tetrahydrofuran }\end{array}$ & $\begin{array}{c}80 \% \text { tetrahydrofuran } \\
\text { in water at } 65^{\circ} \mathrm{C} \text { for } \\
30 \mathrm{~min}\end{array}$ & methanol & $590 \mathrm{~nm}$ & [16] \\
\hline $\begin{array}{l}\text { A spectrophotometric } \\
\text { method }\end{array}$ & $5 \mathrm{~g}$ & $30 \%$ ethanol & $\begin{array}{l}\text { freeze drying for } 24 \mathrm{~h} \\
\text { at }-30^{\circ} \mathrm{C}\end{array}$ & methanol & $590 \mathrm{~nm}$ & {$[20]$} \\
\hline $\begin{array}{l}\text { A spectrophotometric } \\
\text { method }\end{array}$ & - & $80 \%$ acetone & $10 \mathrm{~min}$ at $65^{\circ} \mathrm{C}$. & $\begin{array}{c}\text { Solid-Phase } \\
\text { extraction with } \\
\text { column, methanol }\end{array}$ & $590 \mathrm{~nm}$ & [21] \\
\hline $\begin{array}{l}\text { A spectrophotometric } \\
\text { method }\end{array}$ & $105 \mathrm{mg}$ & $\begin{array}{l}90 \% \text { acetone } \\
\text { extract under } \\
\text { temperature } \\
55^{\circ} \mathrm{C}\end{array}$ & $1.5 \mathrm{~h}$ at $55^{\circ} \mathrm{C}$ & $90 \%$ acetone & $590 \mathrm{~nm}$ & [19] \\
\hline
\end{tabular}

This paper focuses on designing a development method of differential spectrometry analysis to examine naphthodianthrones in buckwheat plant extract with $90 \%$ aqueous acetone. This method consists of a combination of differential spectrometry that takes into account the effects of temperature and light. The possible steps of fagopyrin biosynthesis in intact plants and under in vitro conditions, which can be affected by temperature and light, were described.

\section{Results}

Quantitative analyses often involve the spectrophotometric resolution of mixtures of two components with partly overlapping spectra, and the greater the extent of overlap, the more difficult the resolution. Not surprisingly, this topic has been the subject of a number of chemometric studies originally intended for the resolution of binary mixtures and later extended to three or more components $[20,22,23]$. The use of differential spectrometry for the quantitative determination of the presence of napthdiantrone fagopyrin and its precursors showed that in intact buckwheat plants extracts, the 2-(piperidine-2-yl)-emodindianthron-(Z)-2,24,4',5.5'hexahzdroxy-7,7'-dimetyl-3,3'-di(piperidin-2-yl)-10H,10'H-[9,9'-bianthacenylidene]-10,10'dione (Figure 1) was mostly present. 
A

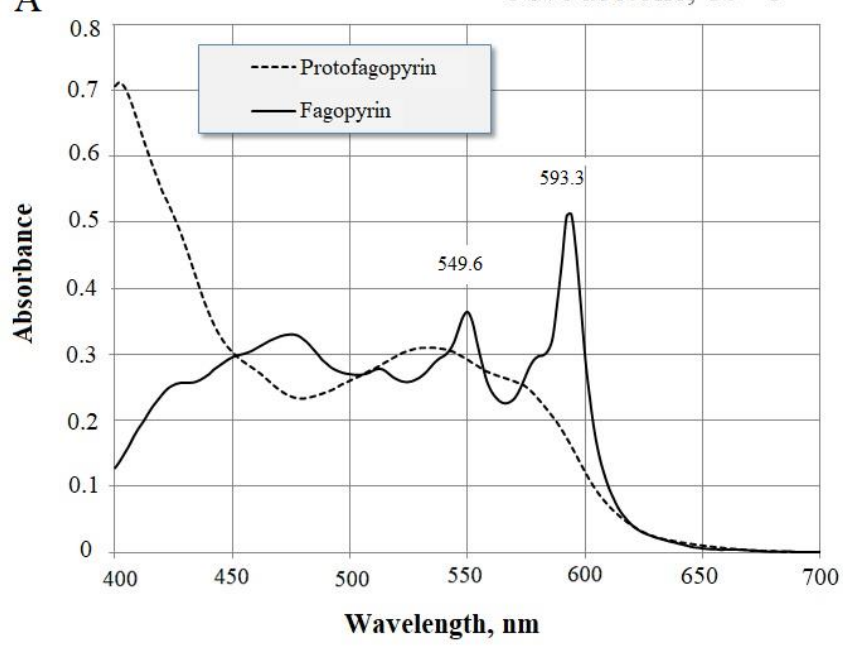

B

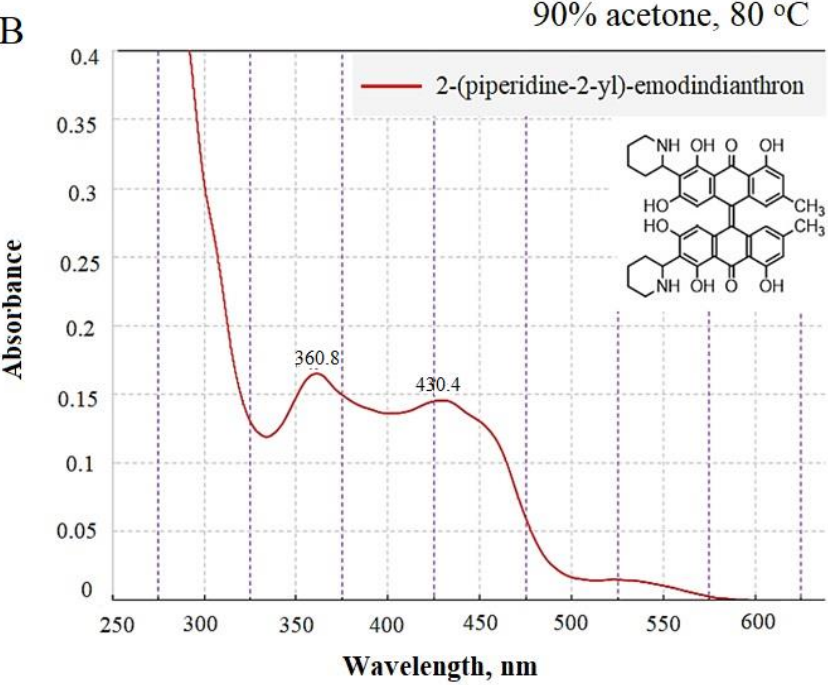

Figure 1. Absorbance spectrum of identified protofagopyrin and fagopyrin spectrum in vitro (A) and 2-(piperidine-2-yl)emodindianthron in intact plants (B) (method of differential spectrophotometry).

The spectrum for the identification of fagopyrins group was in the range from $360.8 \mathrm{~nm}$ to $430.4 \mathrm{~nm}$ (Figure 1B). Fagopyrins are a group of at least eight red- to violet-colored crystalline compounds with strong adhesion to glass that appear pink when dissolved in DMSO and fluoresce orange under $366 \mathrm{~nm}$ light [14,24]. Fagopyrins fluoresce orange to red under UV light at $366 \mathrm{~nm}$. Fluorescence detection was done using an excitation wavelength of $330 \mathrm{~nm}$ and an emission wavelength of $590 \mathrm{~nm}$ [14]. So, in the present study with UV spectroscopic analysis, we monitored the presence of fagopyrins compounds in the wavelength ranging from $360.8 \mathrm{~nm}$. The hypericin, protofagopyrin, fagopyrin $\mathrm{A}$, fagopyrin E, and fagopyrin $\mathrm{F}$ are currently known, and these five yet remaining to be elucidated [12]. As spectrum 420-430.4 is typical for piperidine [25], we suggested that the identified compound may contain 2-(piperidine-2-yl) (Figure 1B). The isolated compound was attached to cationite and visible separation of emodin was observed. As result of such experimental observations, we concluded that 2-(piperidine-2-yl)-emodindianthron can be a possible precursor for farther steps of fagopyrin synthesis.

The protofagopyrin formation during the process of naphthodianthrone isolation in vitro was found to be possible under the influence of temperature and may depend on the duration of temperature treatment. The temperature effect on protofagopyrin formation was studied in the range from 0 to $100{ }^{\circ} \mathrm{C}$ with the identification of protofagopyrin absorbance during $180 \mathrm{~min}$ ( or $2 \mathrm{~h}$ ). The experimental study of protofagopyrin formation under different temperature conditions showed that the fastest protofagopyrin formation was during $20 \mathrm{~min}$ under the temperature $80^{\circ} \mathrm{C}$ and $100{ }^{\circ} \mathrm{C}$. Nearly $1 \mathrm{~h}$ was needed for protofagopyrin formation under the temperature $60{ }^{\circ} \mathrm{C}$ (Figure 2).

Quantitively analysis and calculation of protofagopyrin content showed mostly similar levels for $80^{\circ} \mathrm{C}$ and $100{ }^{\circ} \mathrm{C}$ temperature treatments. It was estimated to be $0.64 \pm 0.03 \mathrm{mg}$ per $\mathrm{g}$ DW for variants with the temperature treatment of $80^{\circ} \mathrm{C}$.

The identified absorbance spectrum for fagopyrin and protofagopyrin were in the range from 549-593 nm (Figure 1A), which are similar to hypericin absorbance [26] but their identification were done under further extraction condition in vitro with the use of temperature treatment and light exposition (Figure 3). One of the scientific theories of fagopyrin formation is supported by the experiment where protofagopyrins were observed in a light-protected extract sample using an HPLC-DAD instrument as a weak signal at $590 \mathrm{~nm}$; they showed that the retention times were similar, but not equal, to those of fagopyrins from an identical but light-exposed sample. Before light exposure, there were no fagopyrin peaks in the sample. In the UV-vis spectra, a strong absorbance maximum at $590 \mathrm{~nm}$ was observed upon exposure to light, indicating the formation 
of fagopyrins [14]. The present study found that fagopyrin formation in vitro can be influenced by high temperature in case of formation of protofagopyrin from 2-(piperidine2-yl)-emodindianthron and by light effect during 5-15 min for fagopyrin formation.

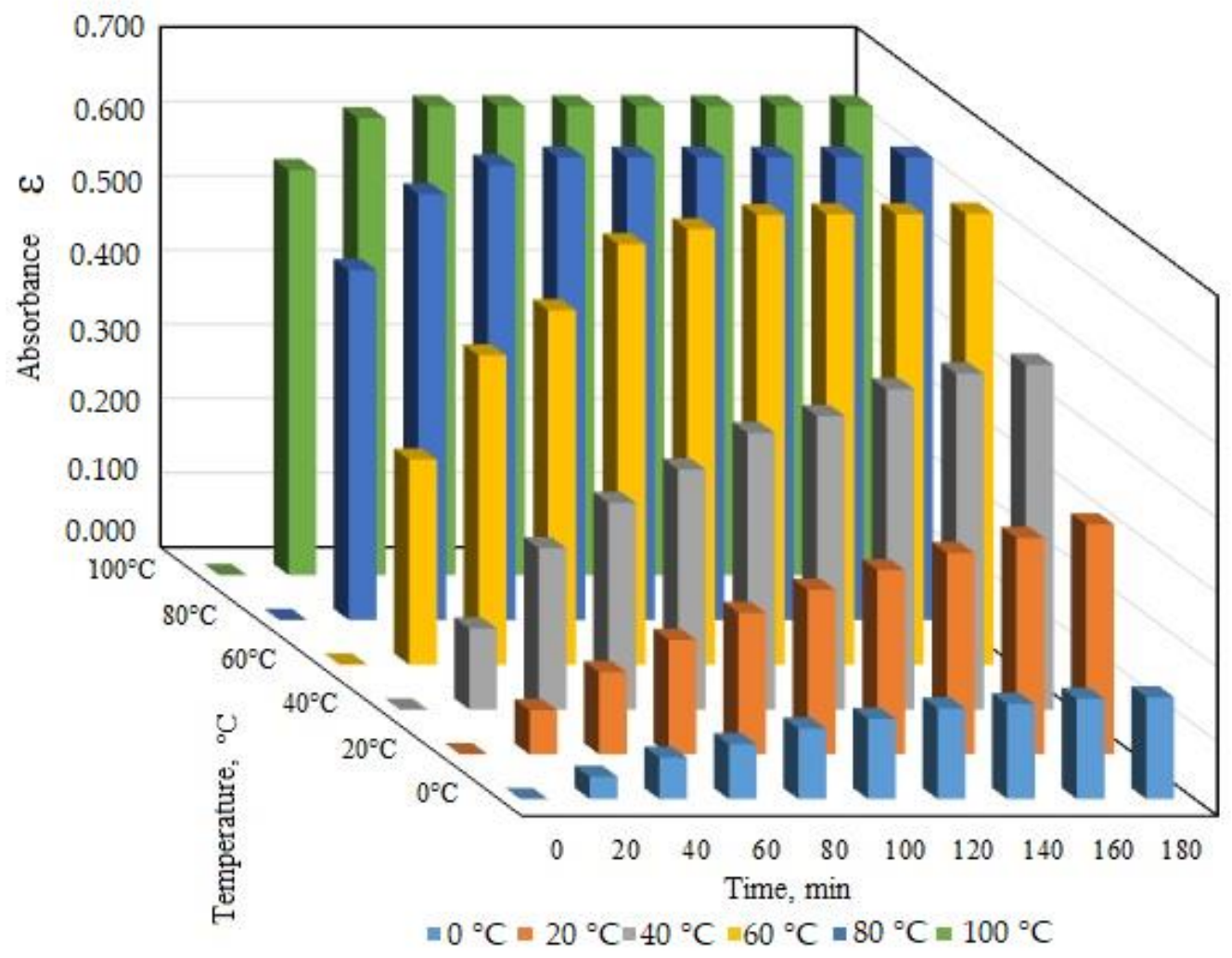

Figure 2. Identified absorbance spectrum of protofagopyrin under different temperature treatment conditions ( $90 \%$ acetone).

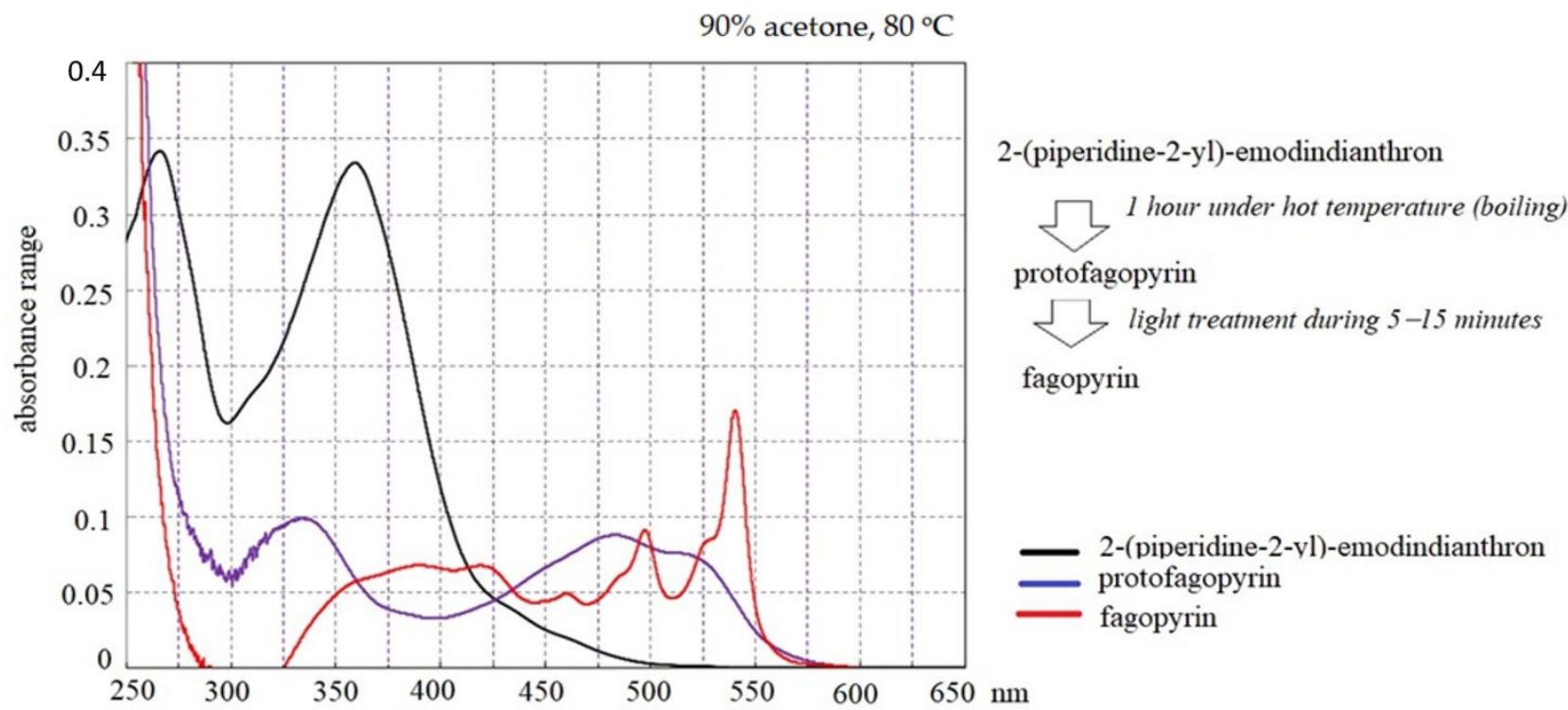

Figure 3. Absorbance spectrum of compounds analyzed by differential spectrophotometry.

The content of 2-(piperidine-2-yl)-emodindianthron, protofagopyrin, and fagopyrin determined in the different steps by differential spectrophotometry is presented in Table 2. It is visible that content of studied 2-(piperidine-2-yl)-emodindianthron, protofagopyrin and fagopyrin are in the range from $0.67 \mathrm{mg}$ per $\mathrm{g}$ DW to $0.70 \mathrm{mg}$ per $\mathrm{g}$ DW. 
Table 2. The content of 2-(piperidine-2-yl)-emodindianthron, protofagopyrin, and fagopyrin determined by differential spectrophotometry.

\begin{tabular}{ccc}
\hline Compound & Conditions of Determination by Differential Spectrophotometry & Content mg per g DW \\
\hline 2-(piperidine-2-yl)-emodindianthron & Extract with 90\% aquatic acetone & $0.64+0.05$ \\
\hline protofagopyrin & $80{ }^{\circ} \mathrm{C}$ temperature treatment, duration 20 min & $0.64+0.03$ \\
\hline protofagopyrin & $60{ }^{\circ} \mathrm{C}$ temperature treatment, duration 60 min & $0.70+0.04$ \\
\hline fagopyrin & LED lamp with a power of 10 watts, 10-15 min & $0.69+0.07$ \\
\hline
\end{tabular}

\section{Discussion}

Kim and Hwang, 2020 identified the presence of fagopyrin A-E using mass-spectrometry analysis with a major peak for fagopyrin $\mathrm{F}$ in the chromatogram in samples from the different parts of common and tartary buckwheat during their flowering period [13]. The presence of different forms of fagopyrins was confirmed but a detailed analysis of their characterisitics and their biosynthesis was not done. The results of the present study with the use of differential spectroscopy showed in intact plants the likely presence of 2-(piperidine-2-yl)-emodindianthron (precursor of fagopyrin) with further formation of protofagopyrin and fagopyrin under conditions in vitro. The spectrum range for the identification of fagopyrin precursor (piperidine-2-yl)-emodindianthron was ranging from $360.8 \mathrm{~nm}$ to $430.4 \mathrm{~nm}$. Milan et al., 2013 found that spectrum in the range $420-430.4$ is typical for piperidine, which helped with the conclusion that the identified compound can be 2-(piperidine-2-yl) [25]. At the same time, the isolated compound was attached to cationite with further visible separation of emodin, which showed the presence of emodin. Huang et al., 2014 described more than 9 known schemes in total synthesis, semi-synthesis, and biosynthesis of hypericin. Emodinanthrone condensation can be done via oxidation to protohypericin in pyridine solution in the presence of a little piperidine in a stream of air [27]. In 1999, Falk et al. reported a simple semi-synthetic method, which begin with emodin. Emodin was decreased by stannous chloride to produce emodinanthrone, which was then treated with a solution of pyridine and ferrous sulfate to obtain the condensation product hypericin [28].

Emodin is a precursor in the synthesis of hypericin and fagopyrin [29]. Emodin is a chemical compound of the anthraquinone family, which is characterized by antiviral, antibacterial, and anti-inflammatory effects, among others [30]. It has also been identified as having a potential antiviral activity against coronaviruses such as SARS-CoV-2 [31,32]. In our previous studies, fagopyrin and hypericin were shown to have antifungal and antibacterial properties as well $[10,11]$.

It was observed that fagopyrin formation in vitro can be influenced by high temperature during the phase of protofagopyrin formation and by light effect during 5-15 min for fagopyrin formation. Quinones, like fagopyrin, and also hypericin, express a lightdependent activity [33].

At the same time, the present experimental study of buckwheat $90 \%$ aqueous acetone extracts under different temperature conditions showed that the fastest protofagopyrin formation during $20 \mathrm{~min}$ under the temperature $80^{\circ} \mathrm{C}$ and $100^{\circ} \mathrm{C}$. Nearly $1 \mathrm{~h}$ is needed for protofagopyrin formation under the temperature $60^{\circ} \mathrm{C}$. Toleikyte et al., 2016 , used $80 \%$ aqueous acetone as the extracting agent for nathtodianthrones extraction from buckwheat (Fagopyrum sp.) and ST. John's wort (Hypericum perforatum L.) herbs. The extraction time was set as $10 \mathrm{~min}$ at $65^{\circ} \mathrm{C}$. Extraction was repeated one more time for a complete extraction of naphthodianthrones [21]. Temperature was found to influence the extraction process of fagopyrin compound, which was confirmed with a more detailed analysis and its connection with time duration in our study.

Differential spectroscopy is an elegant and powerful analytical method, based on the relatively simple principles of classical absorption spectroscopy, which can be implemented during pharmaceutical development, in production for process monitoring, and in quality control laboratories [34]. The use of differential spectroscopy over an extended 
wavelength range has several major advantages, which we also observed in our experimental study with fagopyrin derivatives' estimation. In the studied range $360-430 \mathrm{~nm}$, mostly 2-(piperidine-2-yl)-emodindianthron was estimated in the buckwheat extracts. The estimated absorbance spectrum for fagopyrin and protofagopyrin were in the range from $549-593 \mathrm{~nm}$ with the combined analysis of temperature treatment (boiling) and light effect (LED lamp with a power of 10 watts). The protofagopyrin content was identified with the temperatures $80^{\circ} \mathrm{C}$ and $100{ }^{\circ} \mathrm{C}$ for a time duration of $20 \mathrm{~min}$. The light effect for $15 \mathrm{~min}$ was possible to identify fagopyrin content. Quantitative analysis of 2-(piperidine2-yl)-emodindianthron, protofagopyrin, and fagopyrin determined in the different steps by differential spectrophotometry showed their content to be in the range from $0.67 \mathrm{mg}$ per $\mathrm{g}$ DW to $0.70 \mathrm{mg}$ per $\mathrm{g}$ DW. Ozbolt et al. (2008) determined in the leaves of common buckwheat (Fagopyrum esculentum L.) fagopyrin content in a range $0.44-0.64 \mathrm{mg}$ per $\mathrm{g}$ DW [16]. The experimental results of differential spectrophotometry analysis of green part of buckwheat may show missing gaps in the fagopyrin biosynthesis, which previously were known as emodinanthrone-protofagopyrin-fagopyrin biosynthesis [26]. The suggested fagopyrin and hypericin biosynthesis with updates based on the presented experimental results are presented in Figure 4.

all metabolism goes in intact plants of Hypericum sp.<smiles>O=C1c2c(O)cc(O)cc2-c2c(ccc(O)c2O)C1c1ccc(O)cc1O</smiles>

Emodindianthron

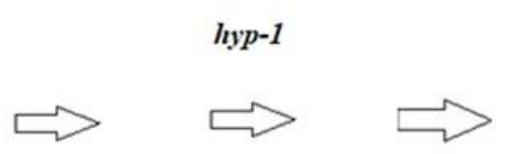

$\mathrm{HO}$<smiles></smiles>

Protohypericin

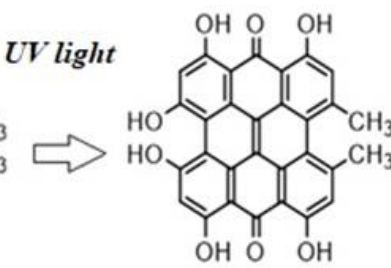

Hypericin<smiles>Cc1cc(O)cc2c(=O)c3c(O)cc(O)cc3c3c(O)c(O)cc(C)c3c12</smiles>

Emodindianthron

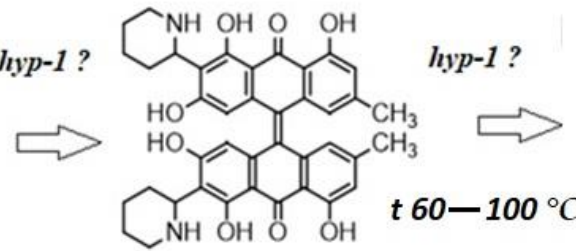

2-(piperidine-2-yl)-emodindianthron

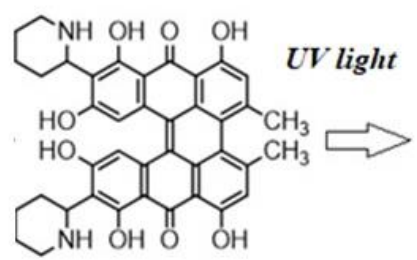

Protofagopyrin

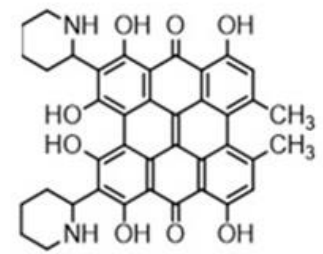

Fagopyrin

Stage 1. Biosynthesis in intact plants of Fagopyrum sp.

Stage 2. Protofagopyrin and fagopyrin formation in vitro

Figure 4. The suggested fagopyrin and hypericin biosynthesis with updates based on the presented experimental results.

Conversion of the protoforms to hypericin and pseudohypericin goes under the effect of light, but protein enzyme hyp- 1 has also been suggested to participate in these reactions [35-37]. The chemical synthesis of hypericin has been achieved by following the pattern of the biosynthesis, using emodidianthron as a precursor [38,39]. In vivo, hypericin 
is synthesized via emodin dimerization in a complicated multistep reaction. This reaction is catalyzed by a small $(17.8 \mathrm{kDa})$ protein, Hyp-1 [37]. We suppose that emodidianthron is a precursor for 2-(piperidine-2-yl)-emodindianthron and protofagopyrin. There is a possibility that fagopyrin synthesis is a multistep reaction that may be catalyzed by protein Hyp-1 or a similar one. The 2-(piperidine-2-yl)-emodindianthron was found to be in high quantity in buckwheat plants. We also suppose that emodidianthron is a precursor for 2-(piperidine-2-yl)-emodindianthron and protofagopyrin. The last reaction of fagopyrin synthesis is protofagopyrin conversion to fagopyrin on exposure to light [40]. In HPLC methods which were developed by Eguschi et al., 2009, vials were exposed to a light for $24 \mathrm{~h}$ at $4{ }^{\circ} \mathrm{C}$ to convert protofagopyrin to fagopyrin [17]. Alali et al., 2004, have reported that protohypericin in hypericin-containing HPLC vials is converted to HYP on exposure to light immediately before HPLC analysis [41], which shows a difference in hypericin and fagopyrin formation. The light influence was confirmed by the current study as well. Sha et al.,2019, standardized the optimum extraction conditions for fagopyrins analysis as follows:an extraction time of $1.5 \mathrm{~h}, 85 \%$ acetone, and an extraction temperature of $55^{\circ} \mathrm{C}$ [19]. Toleikytè et al., 2016, standardized another optimum extraction condition for fagopyrins analysis but showed the same connection with temperature. The extraction was done under $65^{\circ} \mathrm{C}$. [21]. At the same time Hinneburg and Neubert, observed that an extract with a high content of phenolics and antioxidant activity but with a low content of the phototoxic fagopyrin can be obtained by agitated maceration with 30\% ethanol at $60{ }^{\circ} \mathrm{C}$ for $2 \mathrm{~h} \mathrm{[20].} \mathrm{As} \mathrm{we} \mathrm{see,} \mathrm{temperature} \mathrm{factor} \mathrm{is} \mathrm{very} \mathrm{important} \mathrm{for} \mathrm{the} \mathrm{optimal} \mathrm{and}$ faster extraction process and is confirmed by the present study as well. It was found that nearly $1 \mathrm{~h}$ was needed for the protofagopyrin formation under the temperature of $60^{\circ} \mathrm{C}$. Under temperature $80-100{ }^{\circ} \mathrm{C}$, protofagopyrin formation was observed during $20 \mathrm{~min}$. As fagopyrin can be produced by light effect, the temperature factor may influence the formation of protofagopyrin in vitro.

\section{Material and Methods}

\subsection{Plant Material}

The buckwheat (Fagopyrum esculentum L.) plants were grown in the experimental field of Department of Plant Biology, Educational and Scientific Center "Institute of Biology and Medicine", Taras Shevchenko National University of Kyiv, Ukraine. The plant material for fagopyrin and hypericin determination was collected at the flowering period from Fagopyrum esculentum L. Cultivar Rubra of Fagopyrum esculentum L. with high anthocyanins content (3.87-4.41 mg/100 g DW) in the vegetative organ has been received by family selection method from chemo mutants from Taras Shevchenko National University of Kyiv [2]. The vegetative part was collected and frozen in liquid nitrogen to prevent the volatilization of phenolics. Later, samples were lyophilized.

\subsection{Quantitative Determination of 2-(piperidine-2-yl)-emodindianthron, Protofagopyrin and Fagopyrin by Differential Spectrophotometry}

Fagopyrin was determined using the method of differential spectrophotometry developed by us. The description of this method can be found below. The exact weight of the dry material $(25-50 \mathrm{mg}$ ) was milled in a porcelain mortar with $200 \mathrm{mg}$ of glass powder. The milled substrate was transferred in a centrifuge tube. Ten milliliter of $90 \%$ aqueous acetone was added to it, fixed with cap, shaked, and placed in a thermostat at different temperatures $\left(20^{\circ} \mathrm{C}, 40{ }^{\circ} \mathrm{C}, 60^{\circ} \mathrm{C}, 80^{\circ} \mathrm{C}, 100^{\circ} \mathrm{C}\right)$ for $2 \mathrm{~h}$. The optimal temperature for the analysis of 2-(piperidine-2-yl)-emodindianthron and protofagopyrin was found to be $80^{\circ} \mathrm{C}$. The reaction mixture was shaken vigorously for the first $15 \mathrm{~min}$.

In a further step for the identification of 2-(piperidine-2-yl)-emodindianthron from 2 experimental test tubes, $4 \mathrm{~mL}$ of extract was taken from each and transferred to centrifuge tubes. To one aliquot $50 \mathrm{mg}$ of Dowex $50 \times 8$ (200-400 mesh) cationite in $\mathrm{H}^{+}$form was added and mixed for $5 \mathrm{~min}$. This was followed by centrifugation at $2000 \times g$ for $3 \mathrm{~min}$. 
After the incubation in a thermostat, the tube with the experimental mixture was irradiated with a sunlight stream for $15 \mathrm{~min}$. An LED lamp with a power of 10 watts $10 \mathrm{~W}$ (GLS LED Light Bulbs B22 BC Bayonet Paul Russells, Dublin, Ireland) was used and kept at a distance of $10-20 \mathrm{~cm}$ from the glass test tube containing the mixture. As a result of rapid illumination, the mixture in the test tube started precipitating, and so the extract was centrifuged at $2000 \times g$ for $3 \mathrm{~min}$.

The absorbance of the mixture for protofagoyrin and fagopyrin was evaluated at $593 \mathrm{~nm}$. The absorbance for 2-(piperidine-2-yl)-emodindianthron was evaluated at $430.4 \mathrm{~nm}$. An aliquot-treated cation extract was used as an optical control. The experimental samples were measured spectrophotometrically with spectrophotometer UV-1800 (Shimadzu, Tokyo, Japan). The quantity of fagopyrin is determined as follows:

$$
x=\frac{D \times M W \times V}{\varepsilon \times a}
$$

where, $x$ is the protofagoyrin, fagopyrin content in the sample, $\mathrm{mg} \cdot \mathrm{g}^{-1} ; D$ is the optical density of extract; $M W$ is the molecular weight of fagopyrin, 670.71; $V$ is the volume of extract, $\mathrm{ml} ; \varepsilon$ is the coefficient of molar extinction of hypericin, 43,$700 ; a$ is the weight of plant material, g.

\subsection{Statistical Analysis}

Complete findings are represented as mean $\pm \mathrm{SE}$, and alterations between means were analyzed using the ANOVA program, providing statistical significance $(p<0.05)$ for each result.

\section{Conclusions}

The developed method of differential spectrophotometry can be used for the identification of naphthodianthrones fagopyrins. The precursor of fagopyrin in its native form 2-(piperidine-2-yl)-emodindianthron was identified via the method of differential spectrophotometry as a major compound in intact buckwheat plants. It was observed that temperature factor may influence formation of protofagopyrin in vitro. It was shown that nearly $1 \mathrm{~h}$ was needed for the formation of protofagopyrin at a temperature of $60^{\circ} \mathrm{C}$. Under temperature $80-100^{\circ} \mathrm{C}$, protofagopyrin formation was observed during $20 \mathrm{~min}$. The suggested fagopyrin and hypericin biosynthesis scheme with updates based on the presented experimental results showed possible difference in metabolism in the intact plants of Fagopyrum sp. and Hypericum sp. The developed method of differential spectrometry analysis and results of this study can be used in further studies. It is recommended to use described method together with mass spectrometry analysis to analyze the presence of fagopyrins in the different buckwheat cultivars and species.

Author Contributions: A.K. and O.S.-conceptualization. A.K.-investigation. A.K. and O.S.-data analysis contribution. O.S. and A.K.- -writing. All authors have read and agreed to the published version of the manuscript.

Funding: This research received no external funding.

Data Availability Statement: Not applicable.

Conflicts of Interest: The authors declare no conflict of interest.

Sample Availability: Samples of the compounds are not available from the authors. 


\section{References}

1. Sytar, O. Phenolic acids in the inflorescences of different varieties of buckwheat and their antioxidant activity. J. King Saud Univ. Sci. 2015, 27, 136-142. [CrossRef]

2. Sytar, O.; Kosyan, A.; Taran, N.; Smetanska, I. Anthocyanin's as marker for selection of buckwheat plants with high rutin content. Gesunde Pflanz. 2014, 66, 165-169. [CrossRef]

3. Singh, M.; Malhotra, N.; Sharma, K. Buckwheat (Fagopyrum sp.) genetic resources: What can they contribute towards nutritional security of changing world? Genet. Resour. Crop Evol. 2020, 67, 1639-1658. [CrossRef]

4. Sytar, O.; Brestic, M.; Zivcak, M.; Tran, L.S. The Contribution of Buckwheat Genetic Resources to Health and Dietary Diversity. Curr. Genom. 2016, 17, 193-206. [CrossRef]

5. Zhang, K.; He, M.; Fan, Y.; Zhao, H.; Gao, B.; Yang, K.; Li, F.; Tang, Y.; Gao, Q.; Lin, T.; et al. Resequencing of global Tartary buckwheat accessions reveals multiple domestication events and key loci associated with agronomic traits. Genome Biol. 2021, 22, 23. [CrossRef]

6. Huda, N.; Lu, S.; Jahan, T.; Ding, M.; Jha, R.; Zhang, K.; Zhang, W.; Georgiev, M.I.; Park, S.U.; Zhou, M. Treasure from garden: Bioactive compounds of buckwheat. Food Chem. 2021, 335, 127653. [CrossRef]

7. Brockmann, H.; Lackner, H. Zur Konstitution des Fagopyrins. Tetrahedron Lett. 1979, 20, 1575-1578. [CrossRef]

8. Frohne, D.; Pfander, H.J. Poisonous Plants, a Handbook for Pharmacists, Doctors, Toxicologists, Biologists and Veterinarians, 2nd ed.; Timber Press: Portland, OR, USA, 2005; p. 450.

9. Dai, T.; Huang, Y.-Y.; Hamblin, M.R. Photodynamic therapy for localized infections-State of the art. Photodiagn. Photodyn. Ther. 2009, 6, 170-188. [CrossRef]

10. Sytar, O.; Švedienè, J.; Ložienè, K.; Paškevičius, A.; Kosyan, A.; Taran, N. Antifungal properties of hypericin, hypericin tetrasulphonic acid and fagopyrin on pathogenic fungi and spoilage yeasts. Pharm. Biol. 2016, 54, 3121-3125. [CrossRef]

11. Zambounis, A.; Sytar, O.; Valasiadis, D.; Hilioti, Z. Effect of photosensitisers on growth and morphology of Phytophthora citrophthora coupled with leaf bioassays in pear seedlings. Plant Prot. Sci. 2020, 56, 74-82. [CrossRef]

12. Tavčar Benković, E.; Kreft, S. Fagopyrins and protofagopyrins: Detection, analysis, and potential phototoxicity in buckwheat. J. Agric. Food Chem. 2015, 63, 5715-5724. [CrossRef]

13. Kim, J.; Hwang, K.T. Fagopyrins in different parts of common buckwheat (Fagopyrum esculentum) and tartary buckwheat (F. tataricum) during growth. J. Food Compos. Anal. 2020, 86, 103354. [CrossRef]

14. Tavčar Benković, E.; Žigon, D.; Friedrich, M.; Plavec, J.; Kreft, S. Isolation, analysis and structures of phototoxic fagopyrins from buckwheat. Food Chem. 2014, 143, 432-439. [CrossRef] [PubMed]

15. Hagels, H.; Wagenbreth, D.; Schier, H. Phenolic compounds of buckwheat herb and influence of plant and agricultural factors (Fagopyrum esculentum Moench and Fagopyrum tataricum Gartner). Curr. Adv. Buckwheat Res. 1995, 115, 801-809.

16. Ožbolt, L.; Kreft, S.; Kreft, I.; Germ, M.; Stibilj, V. Distribution of selenium and phenolics in buckwheat plants grown from seeds soaked in Se solution and under different levels of UV-B radiation. Food Chem. 2008, 110, 691-696. [CrossRef]

17. Eguchi, K.; Anase, T.; Osuga, H. Development of a high-performance liquid chromatography method to determine the fagopyrin content of tartary buckwheat (Fagopyrum tartaricum Gaertn.) and common buckwheat (F. esculentum Moench). Plant Prod. Sci. 2009, 12, 475-480. [CrossRef]

18. Christa, K.; Soral-Smietana, M. Buckwheat grains and buckwheat products: Nutritional and prophylactic value of their components-A review. Czech J. Food Sci. 2008, 26, 153-162. [CrossRef]

19. Sha, L.U.; Li, Y.-Q.; Li, B.-C.; Ma, M.-C. Research of fagopyrins isolation from buckwheat and analysis of the difference in content between species and varieties. Nat. Prod. Res. Dev. 2018, 49-56. [CrossRef]

20. Hinneburg, I.; Neubert, R.H. Influence of extraction parameters on the phytochemical characteristics of extracts from buckwheat (Fagopyrum esculentum) herb. J. Agric. Food Chem. 2005, 53, 3-7. [CrossRef]

21. Toleikytė, L.; Žvikas, V.; Jakštas, V. Isolation and analysis of naphthodianthrones in buckwheat (Fagopyrum esculentum) and St. John's wort (Hypericum perforatum) plant extracts. In The 7th International Pharmaceutical Conference "Science and Practice 2016", Dedicated to the 240th Anniversary of Prof. Johann Friedrich Wolfgang: Book of Abstracts: October 20-21, 2016, Kaunas, Lithuania/Faculty of Pharmacy of Lithuanian University of Health Sciences [et al.]; Lithuanian university of Health Sciences: Kaunas, Lithuania, 2016; pp. $45-46$.

22. Brown, S.D.; Barker, T.Q.; Larivee, R.A.; Monfre, S.L.; Wilk, H. Chemometrics: Fundamental review. Anal. Chem. 1988, 60, 252R-274R. [CrossRef]

23. Hargis, L.G.; Howell, J.A. Ultraviolet and light absorption spectrometry. Anal. Chem. 1988, 60, 131R-146R. [CrossRef] [PubMed]

24. Wender, S.H.; Gortner, R.A.; Inman, O.L. The isolation of photosensitizing agents from buckwheat. J. Am. Chem. Soc. 1943, 65, 1733-1735. [CrossRef]

25. Milan, D.; Rojas, M.; Pavez, P.; Isaacs, M.; Diaz, C.P.; Santos, J.G. Influence of the ionic liquid on the rate and the mechanism of reaction of p-nitrophenyl acetate with secondary alicyclic amines. New J. Chem. 2013, 37, 3281. [CrossRef]

26. Kubin, A.; Loew, H.G.; Burner, U.; Jessner, G.; Kolbabek, H.; Wierrani, F. How to make hypericin water-soluble. Pharmazie 2008, 63, 263-269. [PubMed]

27. Huang, L.F.; Wang, Z.H.; Chen, S.L. Hypericin: Chemical synthesis and biosynthesis. Chin. J. Nat. Med. 2014, 12, 81-88. [CrossRef]

28. Falk, H.; Abd-El-Wareth, A.O.; Tran, H.T.; Altmann, R. Synthesis and properties of hypericins substituted with acidic and basic residues: Hypericin tetrasulfonic acid-A water soluble hypericin derivative. Mon. Chem. 1998, 129, 309-318. 
29. Sytar, O.; Brestic, M.; Rai, M. Possible ways of fagopyrin biosynthesis and production in buckwheat plants. Fitoterapia 2013, 84, 72-79. [CrossRef]

30. Monisha, B.A.; Kumar, N.; Tiku, A.B. Emodin and Its Role in Chronic Diseases. Adv. Exp. Med. Biol. 2016, 928, 47-73. [CrossRef] [PubMed]

31. Zhou, Y.; Hou, Y.; Shen, J.; Huang, Y.; Martin, W.; Cheng, F. Network-based drug repurposing for novel coronavirus 2019nCoV/SARS-CoV-2. Cell Discov. 2020, 6, 14. [CrossRef]

32. Ho, T.Y.; Wu, S.L.; Chen, J.C.; Li, C.C.; Hsiang, C.Y. Emodin blocks the SARS coronavirus spike protein and angiotensin-converting enzyme 2 interaction. Antivir. Res. 2007, 74, 92-101. [CrossRef]

33. Ebermann, R.; Alth, G.; Kreitner, M.; Kubin, A. Natural products derived from plants as potential drugs for the photodynamic destruction of tumor cells. J. Photochem. Photobiol. B 1996, 36, 95-97. [CrossRef]

34. Bunaciu, A.A.; Vu Dang, H.; Aboul-Enein, H.Y. Differential spectrophotometry in analytical chemistry. Crit. Rev. Anal. Chem. 2013, 43, 125-130. [CrossRef]

35. Bais, H.P.; Vepachedu, R.; Lawrence, C.B.; Stermitz, F.R.; Vivanco, J.M. Molecularand biochemical characterization of an enzyme responsible for the formation of hypericin in St. John's wort (Hypericum perforatum L.). J. Biolchem. 2003, 278, 32413-32422.

36. Zobayed, S.M.A.; Afreen, F.; Goto, E.; Kozai, T. Plant-environment interactions:accumulation of hypericin in dark glands of Hypericum perforatum. Ann. Bot. 2006, 98, 793-804. [CrossRef] [PubMed]

37. Michalska, K.; Fernandes, H.; Sikorski, M.; Jaskolski, M. Crystal structure ofhyp-1, a St.John's wort protein implicated in the biosynthesis of hypericin. J. Struct. Biol. 2010, 169, 161-171. [CrossRef] [PubMed]

38. Karioti, A.; Bilia, A.R. Hypericins as potential leads for new therapeutics. Int. J. Mol. Sci. 2010, 11, 562-594. [CrossRef]

39. Kubin, A.; Wierrani, F.; Burner, U.; Alth, G.; Cronberger, W. Hypericin-The facts about a controversial agent. Curr. Pharm. Des. 2005, 11, 233-253. [CrossRef]

40. Tavcar, E.; Stojilkovski, K.; Kreft, S. Fagopyrin and its derivatives inbuckwheat (Fagopyrum sp.). Planta Med. 2011, 77, 65. [CrossRef]

41. Alali, F.; Tawaha, K.; Al-Eleimat, T. Determination of hypericin content in Hypericum triquetrifolium Turra (Hypericaceae) growing wild in Jordan. Nat. Prod. Res. 2004, 18, 147-151. [CrossRef] 